\title{
A molibdénellátás hatása kukorica csíranövényekre
}

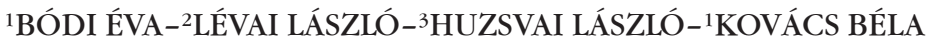 \\ Debreceni Egyetem, Agrár- és Gazdálkodástudományok Centruma \\ ${ }^{1}$ Élelmiszertudományi, Minőségbiztosítási és Mikrobiológiai Intézet, Debrecen \\ ${ }^{2}$ Növénytudományi Intézet, Mezôgazdasági Növénytani és \\ Növényélettani Tanszékcsoport, Debrecen \\ ${ }^{3}$ Gazdaságelemzés-módszertani és Alkalmazott Informatikai Intézet, Debrecen
}

\section{Összefoglalás}

A molibdén alapvetô nyomelem a növényi tápanyagellátásban. Növényélettani jelentôségét 1940-ben bizonyították be. A növény nitrogén anyagcseréjében van fontos szerepe, hiányában nitrát felhalmozódás tapasztalható.

Kutatómunkánk célja kettős volt:

Kísérleteink során egyrészt arra a kérdésre kerestük a választ, hogyan változik a kukorica (Zea mays L. cv Norma SC) csíranövény Mo, Fe és S koncentrációja növekvố koncentrációjú Mo-kezelések során. Azért tartottuk fontosnak e három elem koncentrációjának nyomon követését, mert a nitrátredukcióban, a nitrát-reduktáz múködésében ezek az elemek kiemelt szerepet töltenek be. Másrészt kísérleteinkkel laboratóriumi körülmények között kívántuk igazolni, hogy szoros összefüggés van a molibdénellátás és nitrátredukció között: a növények fiziológiai molibdén szükségletét biztosítva, csökkenteni tudjuk nitrát tartalmukat.

Kísérleteink az alábbi két típusba sorolhatók: rizoboxos- és tápoldatos kísérletek.

Rizoboxos kísérleteinkben három különböző koncentrációjú Mo-kezelést alkalmaztunk: 30, 90, $270 \mathrm{mg} / \mathrm{kg}$. A kontroll talajhoz pedig nem adtunk molibdént.

Tápoldatos kísérleteinkben a kezelések a következók voltak: 0,01 $\mu \mathrm{M}, 0,1 \mu \mathrm{M}, 1 \mu \mathrm{M}$ Mo koncentrációk. A kontroll tápoldat nem tartalmazott molibdént.

Az eredményekből egyértelmúen látható, hogy a Mo-kezelések hatására, a kukorica csíranövények Mo koncentrációja jelentôsen megemelkedett. A kísérleti növények haj- 
tásának és gyökerének külön történô vizsgálata alapján megállapítottuk, hogy a gyökerekben mért Mo-koncentrációk nagyobbak a hajtásban mért értékeknél. Ez arra utal, hogy a gyökerekben, a vizsgált körülmények között a nitrát akkumulációja intenzívebb volt. A molibdénnel ellentétében a kén és a vas koncentrációjának alakulásában nem figyeltünk meg egyértelmú, jelentős növekedést.

Kulcsszavak: molibdén, kukorica, rizobox, tápoldat

\title{
The effect of molybdenum supply on maize seedlings
}

\author{
${ }^{1}$ É. BÓDI-2'L. LÉVAI- ${ }^{3}$ L. HUZSVAI- ${ }^{1}$ B. KOVÁCS \\ University of Debrecen, Centre for Agricultural and Applied Economic Sciences \\ ${ }^{1}$ Institute for Food Sciences, Quality Assurance and Microbiology, Debrecen \\ ${ }^{2}$ Institute for Crop Sciences, Department Group of Agricultural Botany and \\ Crop Physiology, Debrecen \\ ${ }^{3}$ Institute for Economic Analitical Methodology and Applied Informatics, Debrecen
}

\section{Summary}

Molybdenum is a fundamental trace element in the nutrient supply of crops. The crop physiological importance of molybdenum was revealed in 1940. This element has an important role in the nitrogen metabolism of crops, molybdenum shortage is accompanied by nitrate accumulation.

This research work had a dual aim:

The purpose of these experiments was to examine how Mo, Fe and S concentrations change in maize (Zea mays L. cv Norma SC) seedlings as a result of increasing Mo concentration. The reason it was considered to be important to trace the concentrations of these three elements is that they have special roles in nitrate reduction and the functioning of nitrate reductase. Furthermore, these experiments helped to show under laboratory conditions that there is a close correlation between molybdenum supply and nitrate reduction: crops' nitrate content can be reduced while providing their physiological molybdenum need.

These experiments can be classified into the two following groups: rhizobox and nutrient solution experiments. 
Three different concentrations of Mo were used in the rhizobox experiments: 30 , $90,270 \mathrm{mg} \mathrm{kg}^{-1}$. No molybdenum was added to the control soil.

The following treatments were used in the nutrient solution experiments: $0.01 \mu \mathrm{M}$, $0.1 \mu \mathrm{M}, 1 \mu \mathrm{M}$ Mo. The control nutrient solution did not contain any molybdenum.

It can be clearly seen from the results that the Mo concentration of maize seedlings significantly increased as a result of Mo treatments. Based on the separate examination of the shoots and roots of the experimental crops, it was established that Mo concentrations measured in the roots are higher than those of the shoots. This phenomenon refers to the fact that nitrate accumulation was more intensive in the roots under the examined conditions. As opposed to molybdenum, no obvious and significant increase was observed in the concentration of sulphur and iron.

Key words: molybdenum, maize, rhizobox, nutrient solution

\title{
Влияние снабжения молибденом на всходы кукурузы
}

\author{
'Е.БОДИ-2Л. ЛЕВАИ-³Л. ХУЖВАИ-1Б. КОВАЧ \\ Центр Агро-Экономических Наук Дебреценского Университета \\ ${ }^{1}$ Институт Науки о пищевых продуктах, Микробиологии и Обеспечения качества, \\ Дебрецен \\ ${ }^{2}$ Институт Ботаники, группа Кафедры Сельскохозяйственной Фитологии и \\ Фитофизиологии, Дебрецен \\ ${ }^{3}$ Институт Прикладной Информатики и Методики анализа экономики, Дебрецен
}

\section{Резюме}

Молибден - основной микроэлемент в обеспечении питательными веществами растений. Его фитофизиологическое значение доказали в 1940 году. Он играет важную роль в обмене веществ азота растения, при его отсутствии можно обнаружить накопление нитрата.

У нашего исследования была двойная цель:

В ходе наших опытов, с одной стороны, мы искали ответ на вопрос, как изменяется концентрация Мo, Fe и $\mathrm{S}$ всхода кукурузы (Zea mays L. cv Norma SC) в ходе обработок Мо-ом растущей концентрации. Поэтому считали важным отслеживать кон- 
центрацию этих трёх элемнтов, так как эти элементы в редукции нитрата, в действии нитрат-редуктазы играют важную роль. С другой стороны, нашими опытами в лабораторных условиях хотели подтвердить, что есть тесная связь между обеспечением молибденом и редукцией нитрата: обеспечив физиологическую потребность растений в молибдене, можем уменьшить их содержание нитрата.

Наши опыты были двух типов: ризобоксовые и с питательным раствором.

В ризобоксовых опытах мы применяли три обработки Мо-ом различной концентрации: 30, 90, $270 \mathrm{mg} / \mathrm{kg}$. А в контрольную почву не вносили молибден.

В опытах с питательным раствором обработки были следующими: $0,01 \mu \mathrm{M}, 0,1$ $\mu \mathrm{M}, 1 \mu \mathrm{M}$ концентрации Мо. Контрольный питательный раствор не содержал молибден.

Результаты однозначно показывают, что под действием обработок Мо-ом, концентрация Мо всходов кукурузы значительно увеличилась. На основании отдельно происходящих исследований побегов и корней опытных растений мы установили, что измеренная концентрация Мо в корнях больше измеренных величин в побеге. Это говорит о том, что в корнях, в условиях исследования аккумуляция нитрата была интенсивнее. В противоположность молибдену в формировании концентрации серы и железа не заметили однозначное, значительное увеличение.

Ключевые слова: молибден, кукуруза, ризобокс, питательный раствор

\section{Bevezetés és irodalmi áttekintés}

A földkéreg 1,0-2,3 mg/kg molibdént tartalmaz. Ha a talajban elóforduló mikroelemek mennyiségét összehasonlítjuk egymással, akkor megállapíthatjuk, hogy a molibdén a talajokban csak kis mennyiségben van jelen, ez azonban a legtöbb termesztett növény számára elegendő (Simon 1999). A talajok átlagos molibdén koncentrációja Schulte (2004) megállapítása szerint 0,25-5 mg/kg. A talajban a Mo különbözó ásványokban fordul elő, valamint kötött állapotban a vas- és alumínium-hidroxidokhoz kapcsolódva található meg.

Gupta és Lipsett (1981) kutatómunkájuk során rámutattak arra, hogy a talajaink pH-értéke jelentôsen befolyásolja a rajtuk termesztett növények molibdén tartalmát.

Talajaink a molibdént 6 pH alatt igen erôsen kötik, ezért savanyú talajokon könnyen molibdén-hiány léphet fel (Aubert és Pinta 1977). A Mo-felvétel lúgos kémhatású talajokból lényegesen nagyobb fokú. Ennek az az oka, hogy a mik- 
roelemek többségétől eltérôen oldhatósága a lúgos talajokban nagyobb, így valószínúleg a szorpciós komplexek molibdenát ionjai fokozottabb mértékben cserélődnek ki a talajoldat $\mathrm{OH}^{-}$-ionjaival. A talajoldat $\mathrm{OH}^{-}$-ion tartalmának növelése javítja legjobban a Mo felvehetôségét (Berger és Pratt 1965).

A növények molibdén-tartalma általában alacsony, csak ritkán haladja meg az $1 \mathrm{mg} / \mathrm{kg}$ szárazanyag értéket. Felvétele molibdenát-ion formában történik. Nem vándorol a növényben, legnagyobb mennyiségben a háncsrészben és a szállítóedények parenchimájában található (Kalocsai és Pogány 2007).

A növények a Mo-hiányra sokkal érzékenyebbek, mint a molibdén feleslegére. Nem megfelelô Mo-ellátottság esetén csökken a cukortartalom és a fotoszintézis intenzitása, valamint az aszkorbinsav bioszintézise gátolt lesz, így pl. a növényi levelek C-vitamin tartalma a normális érték 1/4-ére is lecsökkenhet. Mo-hiányos növények levélszöveteiben a nitrát akkumulálódik és a növény fehérjetartalma is csökken (Szabó et al. 1987).

A Mo-hiányos növények növekedése lassul, a levelek fakó színúekké válnak és a virágzás is zavart szenved. A Mo-hiány tünetei legtöbbször a középső és az idősebb leveleken jelennek meg. A levelek színe sárgás, gyakori a levélerek közötti klorózis és a levélszélek összepödrődhetnek (Füleky 1999).

Az egyes növények Mo-szükséglete eltérô. A pillangós virágú növények (pl. szója, borsó, bab, lucerna) sokkal több molibdént halmoznak fel, mint más fajok és ez különbözố koncentrációban van jelen az egyes növényi részekben. Szalai (2006) megállapítása szerint a növény nóduszaiban és magvaiban sokkal több a molibdén, mint a vegetatív szervekben. A pillangós virágú növények magasabb molibdén igénye a növények gyökerein lévő gümőbaktériumok jelenlétével van kapcsolatban. Ezeknek a baktériumoknak a nitrogén megkötéséhez a Mo nélkülözhetetlen, ugyanis a nitrogenáz enzim molibdént tartalmaz (Loch és Nosticzius 1992).

Egyes növények különösen érzékenyek a Mo-hiányra, ezért indikátornövényként is használhatók. Ilyen indikátornövény pl. a karfiol, a nyári káposzta, a spenót, a saláta és a paradicsom. A karfiolnál a levéllemez a molibdénhiány fokozódásával egyre jobban elkeskenyedik, szélsôséges esetben pedig ostornyélhez válik hasonlóvá. Ez a „whiptail” (ostorfarkúság) nevú hiánybetegség tünete. A kór másik elnevezése a fonallevelúség, mert a hiányt mutató növényeknél a levéllemez felülete nagymértékben csökken és az idősebb leveleken a fóér mentén csak kisebb szakadozott levéllemez-maradványok találhatók (Katyal és Randhawa 1983, Duval et al. 1991). 
A növények megfelelố molibdénellátásának biztosítása nemcsak a különbözô hiánytünetek elkerülése miatt szükségszerú, hanem azért is létfontosságú, mert a nitrát-reduktáz enzim kofaktoraként kulcsszerepet tölt be a nitrátredukcióban, amely során a nitrát, nitritté redukálódik (Berks et al. 1995). Molibdén hiányában a nitrát-reduktáz elveszti aktivitását, a nitrátredukció folyamata lelassul és ez a nitrát felhalmozódását eredményezi.

A molibdén (Mo) a növények és az állatok számára egyaránt létfontosságú elem. Számos enzim, illetve enzimrendszer alkotója, ezáltal hozzájárul a megfelelő sejtmúködéshez, fejlődéshez, növekedéshez (Reilly 1991).

A nitrát egészségkárosító hatására először a csecsemők anaemiás megbetegedéséhez, súlyosabb esetben fulladásos halálához vezetô methemoglobinémia kialakulása hívta fel a figyelmünket. Methemoglobinémia során a gyomorban nitritté redukálódott nitrát a hemoglobint methemoglobinná alakítja át azáltal, hogy a központi $\mathrm{Fe}^{2+}$ iont $\mathrm{Fe}^{3+}$ ionná oxidálja, így az képtelenné válik az oxigén szállítására. Methemoglobin alacsony koncentrációban (0,5-3,0\%) az egészséges emberek vérkeringésében is előfordul és egészen 10\%-ig nem okoz kóros tünetet, de $10 \%$ fölött már cianózis alakulhat ki és $25 \%$ fölött már pulzusszám növekedést és szapora légzést eredményez (Knowles et al. 1989). A methemoglobin 50\% feletti koncentrációja a vérben fulladásos halált okozhat. Ez jól mutatja, mennyire fontos, hogy a nitrátredukcióban kulcsszerepet játszó nitrát-reduktáz múködése optimális legyen, amihez viszont a megfelelố mennyiségú molibdén jelenléte nélkülözhetetlen.

\section{Anyag és módszer}

Vizsgálatunk tárgyának egy egyszikű (kukorica, Zea mays L. cv Norma SC) növényt választottunk, melynél külön vizsgáltuk a hajtás és a gyökér molibdén koncentrációját.

Kutatómunkánk során figyelemmel kísértük azt is, hogy a molibdén mellett hogyan változik a vas és kén koncentrációja, miközben növeljük a Mo-koncentrációt az egyes kezeléseknél, mivel a nitrátredukcióban kulcsszerepet játszó enzimben, a nitrát-reduktázban, a molibdén mellett a vas (Fe) és a kén (S) is jelen van.

A kukoricanövények nevelését a Növénytudományi Intézet, Mezógazdasági Növénytani és Növényélettani Tanszékcsoport Klímaszobájában végeztük, ahol a környezeti feltételek szabályozottak voltak: a relatív páratartalom (RH) 
65-75\%, a hômérséklet periodicitása $25 / 20{ }^{\circ} \mathrm{C}$ (nappal/éjjel), a fényintenzitás $220 \mu \mathrm{E} \mathrm{m}^{-2} \mathrm{~s}^{-1}$, a megvilágítás/sötét periódus 16 óra/8 óra.

A magvakat, fertôtlenítés után nedves szúrôpapírok között csíráztattuk, geotrópusan stimulálva, $22{ }^{\circ} \mathrm{C}$-on, majd a 2,5-3,0 cm koleoptillal rendelkezô csíranövényeket levegôztetett tápoldatra helyeztük, illetve rizoboxban neveltük (1-2. képek).

1. kép. Tápoldaton nevelt kukorica csíranövények $\left(\varnothing=\mathrm{O} \mathrm{mg} / \mathrm{dm}^{3} \mathrm{Mo}, 100 \times \mathrm{Mo}=1 \mu \mathrm{M}\left(\mathrm{NH}_{4}\right)_{6} \mathrm{Mo}_{7} \mathrm{O}_{24}\right)$

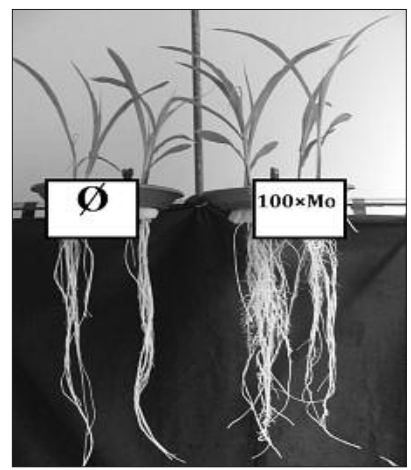

Picture 1. Maize seedlings grown in nutrient solution $\left(\varnothing=0 \mathrm{mg} \mathrm{dm}^{3}\right.$ $\left.\mathrm{Mo}, 100 \times \mathrm{Mo}=1 \mu \mathrm{M}\left(\mathrm{NH}_{4}\right)_{6} \mathrm{Mo}_{7} \mathrm{O}_{24}\right)$

2. kép. Rizoboxban nevelt kukorica csíranövények ( $k=$ kontroll, $90 \mathrm{mg} / \mathrm{kg} \mathrm{Mo}$ )

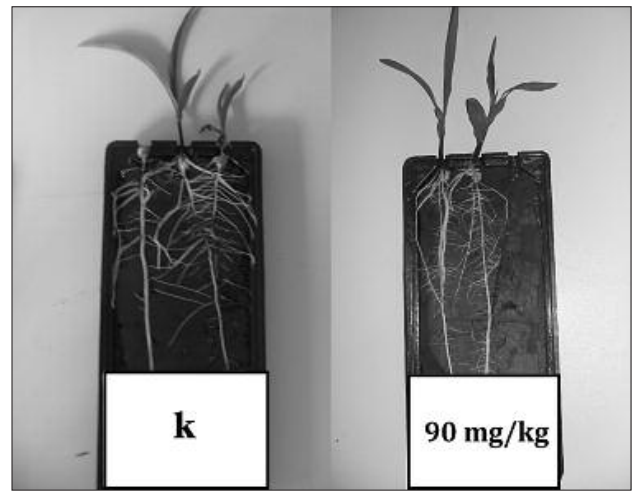

Picture 2. Maize seedlings grown in rhizoboxes ( $\mathrm{k}=$ control, $90 \mathrm{mg} \mathrm{kg}^{-1} \mathrm{Mo}$ ) 


\section{Tápoldaton végzett kísérlet}

Tápoldaton végzett kísérleteinkben a növények neveléséhez az alábbi összetételú tápoldatot használtuk: $2,0 \mathrm{mM} \mathrm{Ca}\left(\mathrm{NO}_{3}\right)_{2}, 0,7 \mathrm{mM} \mathrm{K}_{2} \mathrm{SO}_{4}, 0,5 \mathrm{mM} \mathrm{MgSO}_{4}$, $0,1 \mathrm{mM} \mathrm{KH}_{2} \mathrm{PO}_{4}, 0,1 \mathrm{mM} \mathrm{KCl}, 0,1 \mu \mathrm{M} \mathrm{H}_{3} \mathrm{BO}_{3}, 0,5 \mu \mathrm{MnSO}_{4}, 0,5 \mu \mathrm{M} \mathrm{ZnSO}_{4}$, $0,2 \mu \mathrm{M} \mathrm{CuSO}_{4}, 0,01 \mu \mathrm{M}\left(\mathrm{NH}_{4}\right)_{6} \mathrm{Mo}_{7} \mathrm{O}_{24}$. A növények a vasat $10^{-4} \mathrm{M}$ koncentrációjú Fe-EDTA formájában kapták (Cakmak és Marschner 1990).

A molibdén kiegészítést a tápoldathoz adtuk, a kezeléseknek megfelelóen. A kezelések a következők voltak: Ø Mo, $1 \times$ Mo $(0,01 \mu \mathrm{M}), 10 \times$ Mo, $100 \times$ Mo koncentrációk. Vizsgálatainkat három ismétlésben végeztük el.

A tápoldatot kétnaponta cseréltük és az elpárolgott vizet rendszeresen pótoltuk. A tápoldatos kísérlet bontására az ültetést követô 9. napon került sor. A kiértékeléskor a csíranövényeink megközelítőleg 12-12 cm-es hajtással és gyökérrel rendelkeztek.

\section{Rizoboxos kísérlet}

A rizoboxos kísérlet elónye, hogy a kukorica gyökereinek növekedése, a növekedés napi, napszaki ritmusa is nyomon követhetô, valamint az is látható, hogy a növekvő Mo-koncentráció okoz-e fitotoxikus tüneteket a kísérleti növényeink gyökereinél.

A vizsgálathoz mészlepedékes csernozjom talajt használtunk fel, mely a DE AGTC Látóképi Kísérleti Telepérôl származott.

A kísérletben alkalmazott talaj összetételének a jellemzôi megegyeznek a Nagy et al. (2010) kísérletében felhasznált talajéval és NPK mútrágyázásra ebben a kísérletben sem került sor. A kontroll (k) kezelésú talajhoz nem adtunk molibdént, a kezeléseknél pedig a hozzáadott molibdén koncentrációk a következók voltak: 30, 90 és $270 \mathrm{mg} / \mathrm{kg}$. A talajhoz adott Mo adagokat az 1. táblázat tartalmazza.

A talaj Mo-kezeléseihez használt $\left(\mathrm{NH}_{4}\right)_{6} \mathrm{Mo}_{7} \mathrm{O}_{24} \cdot 4 \mathrm{H}_{2} \mathrm{O}$-t ioncserélt vízben oldottuk fel. Szerettünk volna megbizonyosodni arról, hogy az edényekben lévố talajminták kellô mértékben lettek-e homogenizálva, ezért három különböző részéból vettünk kb. 10-15 g talajt, és a molibdén koncentrációjának elemzésével ellenőriztük a molibdén kezelés megfelelô kivitelezését. 
1. táblázat. Mészlepedékes csernozjom talaj különbözö Mo-kezeléseihez szükséges Mo és $\left(\mathrm{NH}_{4}\right)_{6} \mathrm{Mo}_{7} \mathrm{O}_{24} 4 \mathrm{H}_{2} \mathrm{O}$ mennyiség

\begin{tabular}{cccc}
\hline $\begin{array}{c}\text { Mo-kezelések } \\
(\mathrm{mg} / \mathrm{kg})\end{array}$ & $\begin{array}{c}\text { Talajminta }(\mathrm{kg}) \\
(1)\end{array}$ & $\begin{array}{c}\text { Mo } \\
(\mathrm{g})\end{array}$ & $\begin{array}{c}\left(\mathrm{NH}_{4}\right)_{6} \mathrm{Mo}_{7} \mathrm{O}_{24.4} \mathrm{H}_{2} \mathrm{O} \\
(\mathrm{g})\end{array}$ \\
\hline $\mathrm{k}$ & 4 & 0,0000 & 0,0000 \\
30 & 4 & 0,1241 & 0,2283 \\
90 & 4 & 0,3724 & 0,6850 \\
270 & 4 & 1,1172 & 2,0549 \\
\hline
\end{tabular}

Table 1. The amount of Mo and $\left(\mathrm{NH}_{4}\right)_{6} \mathrm{Mo}_{7} \mathrm{O}_{24} \cdot 4 \mathrm{H}_{2} \mathrm{O}$ needed for the different Mo treatments of calcareous chernozem soil. (1) Mo treatments $\left(\mathrm{mg} \mathrm{kg}^{-1}\right)$, (2) Soil sample (kg).

A talaj előkészítéséhez 6 mm-es lyukátmérôjû szitát használtunk.

Mielőtt a talajt a rizoboxokba raktuk, az egyes rizoboxok aljára ioncserélt vízzel benedvesített szúrốpapírt helyeztünk. Ezáltal biztosítottuk az egyenletes vízfelvételt a növények számára. Miután a csíráztatott magvakat az elkészített talajba helyeztük, a rizoboxok átlátszó oldalát fekete fóliával borítottuk be. A növényeket geotrópusan stimuláltuk, így a gyökerek a nevelőbox fala mentén növekedtek, ami lehetővé tette a gyökér növekedésének nyomonkövetését.

Naponta mértük az egyes rizoboxok tömegét, az egyes növények gyökereinek hosszát és a leadott vízmennyiséget szintén naponta pótoltuk.

A kísérlet befejezésekor a tápoldaton és a rizoboxban nevelt kísérleti növények gyökereit 0,1 M-os HCl-val mostuk át, majd a száraz tömeg meghatározásához a mintákat $85^{\circ} \mathrm{C}$-on tömegállandóságig szárítottuk, és szobahőmérsékletre történô visszahűtésük után analitikai mérlegen (OHAUS) mértük.

Szárítószekrényben történő szárítást és homogenizálást követően a növényminták elemtartalmának meghatározásához a Kovács et al. (1996) által közölt $\mathrm{HNO}_{3}-\mathrm{H}_{2} \mathrm{O}_{2}$-os nedves-roncsolásos minta-elókészítési módszert alkalmaztuk. A minták bemért tömege $1 \mathrm{~g}( \pm 0,01 \mathrm{~g})$ volt. A mintákat a hozzáadott $10 \mathrm{~cm}^{3} \mathrm{cc} . \mathrm{HNO}_{3}$-val együtt egy éjszakán át állni hagytuk. Másnap a mintákat LABOR MIM OE 718/A típusú blokkroncsoló készülék fútőegységébe helyeztük. Ezeket a mintákat 45 percig $60{ }^{\circ} \mathrm{C}$-on kellett elôroncsolni. A fooroncsolás elôtt $3 \mathrm{~cm}^{3} 30 \%-\mathrm{os} \mathrm{H}_{2} \mathrm{O}_{2}$-ot adagoltunk hozzá, majd 90 percig $120{ }^{\circ} \mathrm{C}$-on tartottuk a roncsolmányt. A mintákat lehûlés után $50 \mathrm{~cm}^{3}$-re feltöltöttük ioncserélt vízzel, majd összerázás után FILTRAK 388-as típusú szúroopapírral szűrtük. A minták feltárásánál roncsolási vakpróbát is készítettünk. Az elemtartalmi mé- 
réseket egy OPTIMA 3300 DV típusú induktív csatolású plazma optikai emiszsziós spektrométerrel (ICP-OES), illetve egy X7-es típusú, Thermo Elemental gyártmányú, induktív csatolású plazma tömeg-spektrométerrel (ICP-MS) végeztük, amelyek beállítási és mérési paraméterei megegyeznek Puskás-Preszner és Kovács (2009) által alkalmazott paraméterekkel.

A növényminták $\mathrm{NO}_{3}-\mathrm{N}, \mathrm{NO}_{2}-\mathrm{N}, \mathrm{NH}_{4}-\mathrm{N}$ koncentrációját FIAstar 5000 Analizátor készülék segítségével határoztuk meg.

\section{Statisztikai elemzések}

A kísérleti adatokat kéttényezôs általános lineáris modellel (GLM) értékeltük. Az általános lineáris modell a hagyományos variancia-analízis és a lineáris regresszió-analízis ötvözete. Egyetlen táblázatban jelenik meg a variancia-, és regresszió-analízis eredménye. Az R-négyzet megmutatja, hogy a kezelések milyen mértékben befolyásolták a függôváltozót. Az elemzéseket az SPSS 13.0 statisztikai programmal végeztük.

\section{Eredmények}

\section{Tápoldatban végzett kísérlet}

Tápoldatban végzett kísérleteink során azt tapasztaltuk, hogy a molibdén nélküli tápoldaton nevelt kukorica csíranövények hajtásainak Mo-koncentrációja viszonylag alacsony volt, a csíranövény eredeti molibdén készletét mutatva. A Mo-kezelések hatására monoton növekedett a hajtások molibdén tartalma, amelyet követett a vas és a kén koncentrációjának mérsékeltebb növekedése is. A vas koncentrációja csak a legmagasabb Mo-koncentráció alkalmazásakor növekedett számottevốn. A 2. táblázat adatai alapján azt a következtetést vonhatjuk le, hogy a kén koncentrációját a hajtásban nem befolyásolja a felvehetô Mo mennyisége. Feltételezzük, hogy a levelekben a három vizsgált elem koncentrációja optimális volt, ami nem tette szükségessé a fokozottabb transzportot a gyökérből (2. táblázat). 
2. táblázat. Tápoldaton nevelt kukorica csíranövények hajtásainak

Mo, Fe és S koncentrációja ( $\mathrm{mg} / \mathrm{kg}$ ) Ø Mo (molibdén nélküli tápoldat), $1 \times$ Mo $(0,01 \mu M), 10 \times$ Mo és $100 \times$ Mo-kezelések esetén

\begin{tabular}{cccc}
\hline $\begin{array}{c}\text { Mo-kezelések } \\
(1)\end{array}$ & Mo $(* * *)$ & Fe $(* * *)$ & $\mathrm{S}\left({ }^{\mathbf{n s z}}\right)$ \\
\hline$\varnothing$ Mo & 2,52 & 60,9 & 2049 \\
$1 \times$ Mo & 3,06 & 57,0 & 2152 \\
$10 \times$ Mo & 6,08 & 58,3 & 2359 \\
$100 \times$ Mo & 20,6 & 72,2 & 2367 \\
\hline
\end{tabular}

**** = szignifikancia szint $0,1 \%,{ }^{\text {nsz }}=$ nem szignifikáns

Table 2. The Mo, Fe and $\mathrm{S}$ concentrations $\left(\mathrm{mg} \mathrm{kg}^{-1}\right)$ of the shoots of maize seedlings grown in nutrient solution $\varnothing$ Mo (nutrient solution without molybdenum), $1 \times$ Mo $(0.01 \mu \mathrm{M}), 10 \times$ Mo and $100 \times$ Mo treatments. (1) Mo treatments. ${ }^{* *}=0.1 \%$ significance level, ${ }^{\mathrm{ns}}=$ not significant.

A gyökérben mért koncentrációk eltértek a hajtásban mérttől. Mokezelések hatására a gyökerekben mért Mo-koncentráció jelentôsen emelkedett. A vas koncentrációja a duplájára növekedett az 1x-es és a 10x-es Mo-szinteken. A százszoros Mo-koncentráció viszont jelentősen csökkentette a vas koncentrációját a gyökérben (3. táblázat).

3. táblázat. Tápoldaton nevelt kukorica csíranövények gyökereinek Mo, Fe és S koncentrációja ( $\mathrm{mg} / \mathrm{kg}$ ) Ø Mo (molibdén nélküli tápoldat), $1 \times$ Mo $(0,01 \mu M), 10 \times$ Mo és $100 \times$ Mo-kezelések esetén

\begin{tabular}{cccc}
\hline $\begin{array}{c}\text { Mo-kezelések } \\
(1)\end{array}$ & Mo $(* * *)$ & Fe $\left.{ }^{* * *}\right)$ & $\mathrm{S}\left({ }^{\mathbf{n s z}}\right)$ \\
\hline Mo & 5,78 & 167 & 4644 \\
$1 \times$ Mo & 7,89 & 303 & 4970 \\
$10 \times$ Mo & 17,9 & 331 & 5197 \\
$100 \times$ Mo & 66,5 & 187 & 5076 \\
\hline
\end{tabular}

*** = szignifikancia szint $0,1 \%$, nsz = nem szignifikáns

Table 3. The Mo, Fe and S concentrations $\left(\mathrm{mg} \mathrm{kg}^{-1}\right)$ of the roots of maize seedlings grown in nutrient solution $\varnothing$ Mo (nutrient solution without molybdenum), $1 \times$ Mo $(0.01 \mu \mathrm{M}), 10 \times$ Mo and $100 \times$ Mo treatments. (1) Mo treatments. ${ }^{* * *}=0.1 \%$ significance level, ${ }^{n s}=$ not significant. 
A nitrát redukciója két helyen történhet meg a növényben. A levelekben a redukcióhoz szükséges redukáló erôt a fotoszintézis fényreakciója biztosítja, míg a gyökerekben a légzésből származnak az aktív hidrogén ionok. A gyökerekben mért magasabb molibdén és vas koncentráció arra utal, hogy a kukorica esetében és a vizsgált körülmények között, a gyökerekben intenzívebb a nitrát akkumulációja.

Feltételezésünk szerint összefüggés van a nitrogén-asszimilációban fontos szerepet játszó Mo-szint és a különbözô N-formák között a növényben. Feltételezésünk megerôsítésére kísérleteket állítottunk be, amelyekben eltérô molibdénellátás mellett vizsgáltuk a nitrát, a nitrit és az ammónia szinteket. Fiatal csíra növényeknél a legnagyobb mennyiségben igényelt tápelem a nitrogén. Az intenzív vegetatív növekedés intenzív fehérjeszintézist és fokozott enzim aktivitást igényel.

Mo-hiányos tápoldaton nevelt kukorica csíranövények hajtásaiban a nitrátreduktáz aktivitását a csíranövény eredetileg is meglévô endogén molibdén készlete determinálja. Ennek megfelelóen viszonylag magas a $\mathrm{NO}_{3}-\mathrm{N}$ szint és alacsony az $\mathrm{NH}_{4}-\mathrm{N}$ mennyisége. A fiziológiai Mo-igényt kielégítve $(1 \times \mathrm{Mo}=0,01 \mu \mathrm{M})$ csökkent $\mathrm{NO}_{3}-\mathrm{N}$ és a molibdénmentes tápoldaton mértnél jóval magasabb $\mathrm{NH}_{4}$-N koncentrációt kaptunk. A tízszeres molibdénkezelés hatására jelentôsen noótt a $\mathrm{NO}_{3}-\mathrm{N}$ mennyisége, de növekedett a hajtás $\mathrm{NH}_{4}-\mathrm{N}$ koncentrációja is. A nitrát redukciója induktív folyamat. Amennyiben a közegben csak $\mathrm{NO}_{3}-\mathrm{N}$ van jelen, aktiválódik egy nagy affinitású nitrát felvevô rendszer, azaz fokozódik a nitrát membrántranszportja, ami ugyancsak igényli a molibdént. A tízszeres Mo-koncentrációnál mért magas $\mathrm{NO}_{3}-\mathrm{N}$ koncentráció ennek az összehangolt mechanizmusnak az eredménye. A százszoros Mo-koncentrációnál mért $\mathrm{NH}_{4}-\mathrm{N}$ koncentrációja visszaesett, közel a Mo-mentes értékre (4. táblázat).

A nitrát redukciójának másik lehetséges helye a gyökér. A gyökérben történő nitrátredukció légzéshez kötött, ezért minden olyan környezeti tényezô, amely befolyásolja a légzés intenzitását (pl. talaj hőmérséklet), hatással van a légzéshez kötött fiziológiai folyamatokra is. Kísérletünkben ezért folyamatosan ellenôriztük a tápoldat hômérsékletét $\left(20^{\circ} \mathrm{C}\right)$. A gyökerekben jelentôs koncentrációjú $\mathrm{NO}_{3}$-N és $\mathrm{NH}_{4}$-N-t mértünk a molibdén nélküli tápoldaton. Feltételezzük, hogy a nagy affinitású nitrát felvételi mechanizmuson kívül, más, pl. hagyományos, ATP energiájához kötött proton szimporttal is jelentôs mennyiségú nitrát juthat át a gyökérszőrök plazmamembránján. 
4. táblázat. Tápoldaton nevelt kukorica csíranövények hajtásainak nitrát-( $\left.\mathrm{NO}_{3}-\mathrm{N}\right)$, nitrit-( $\left.\mathrm{NO}_{2}-\mathrm{N}\right)$ és ammónium-nitrogén $\left(\mathrm{NH}_{4}-\mathrm{N}\right)$ koncentrációja ( $\mathrm{mg} / \mathrm{kg}) \varnothing \mathrm{Mo}$ (molibdén nélküli tápoldat), $1 \times$ Mo $(0,01 \mu M), 10 \times$ Mo és $100 \times$ Mo-kezelések esetén

\begin{tabular}{cccc}
\hline $\begin{array}{c}\text { Mo-kezelések } \\
(1)\end{array}$ & $\mathrm{NO}_{3}-\mathrm{N}\left({ }^{\mathrm{nsz}}\right)$ & $\mathrm{NO}_{2}-\mathrm{N}\left({ }^{\mathbf{n s z}}\right)$ & $\mathrm{NH}_{4}-\mathrm{N}\left({ }^{* * *}\right)$ \\
\hline$\varnothing$ Mo & 2153 & 0,59 & 111 \\
$1 \times$ Mo & 1730 & 1,06 & 199 \\
$10 \times$ Mo & 3939 & 1,42 & 160 \\
$100 \times$ Mo & 1772 & 0,73 & 124 \\
\hline
\end{tabular}

*** = szignifikancia szint $0,1 \%,{ }^{\text {nsz }}=$ nem szignifikáns

Table 4. The nitrate $\left(\mathrm{NO}_{3}-\mathrm{N}\right)$, nitrite $\left(\mathrm{NO}_{2}-\mathrm{N}\right)$ and ammonium nitrogen $\left(\mathrm{NH}_{4}-\mathrm{N}\right)$ concentrations $\left(\mathrm{mg} \mathrm{kg}{ }^{-1}\right)$ of the shoots of maize seedlings grown in nutrient solution $\varnothing$ Mo (nutrient solution without molybdenum), $1 \times$ Mo $(0.01 \mu \mathrm{M}), 10 \times$ Mo and $100 \times$ Mo treatments. (1) Mo treatments. $* * *=0.1 \%$ significance level, ${ }^{n s}=$ not significant.

A gyökerek magas $\mathrm{NH}_{4}$-N tartalma a molibdén nélküli tápoldaton, összefüggésben lehet azzal, hogy a gyökerek Mo-koncentrációja a molibdén nélküli tápoldaton nevelt kukorica csíranövényeknél kétszerese volt a levelekben mért koncentrációhoz viszonyítva, ami hatékony nitrát felvételt és redukciót eredményezett. A gyökerekben a százszoros molibdénkezelés adott kiugró eredményt, ami azt jelentheti, hogy a levelek és a gyökerek Mo-érzékenysége eltérô (5. táblázat).

Az általános lineáris modellel végzett analízisek eredményeit mutatják a 6-8. táblázatok. A molibdén-kezelés és a növényi rész együttesen 90-99\%-ban befolyásolta a kukorica csíranövény száraz tömegét, Mo, Fe és S-tartalmát. A molibdén-tartalom alakulásában a molibdén-kezelésnek sokkal nagyobb a hatása, mint a növényi résznek. A másik két elem esetében a növényi rész hatása egy nagyságrenddel nagyobb, mint a molibdénkezelésé. A nitrogénformák közül a molibdénkezelés nem befolyásolta a $\mathrm{NO}_{3}-\mathrm{N}$ és $\mathrm{NO}_{2}-\mathrm{N}$ tartalmat, legalábbis statisztikailag nem lehetett kimutatni a hatást. Ez azért lehetséges, mert nagy a csoportokon belüli szórás. E két nitrogénforma mennyiségét elsôsorban a növényi részek határozzák meg. 
5. táblázat. Tápoldaton nevelt kukorica csíranövények gyökereinek nitrát-( $\left.\mathrm{NO}_{3}-\mathrm{N}\right)$, nitrit- $\left(\mathrm{NO}_{2}-\mathrm{N}\right)$ és ammónium-nitrogén $\left(\mathrm{NH}_{4}^{-\mathrm{N}}\right)$ koncentrációja ( $\mathrm{mg} / \mathrm{kg}) \varnothing \mathrm{Mo}$ (molibdén nélküli tápoldat), $1 \times$ Mo $(0,01 \mu M), 10 \times$ Mo és $100 \times$ Mo-kezelések esetén

\begin{tabular}{cccc}
\hline $\begin{array}{c}\text { Mo-kezelések } \\
(1)\end{array}$ & $\mathrm{NO}_{3}-\mathrm{N}\left({ }^{\mathbf{n s z}}\right)$ & $\mathrm{NO}_{2}-\mathrm{N}\left({ }^{\mathbf{n s z}}\right)$ & $\mathrm{NH}_{4}-\mathrm{N}(* * *)$ \\
\hline Mo & 4407 & 2,28 & 703 \\
$1 \times$ Mo & 4611 & 2,27 & 914 \\
$10 \times$ Mo & 4934 & 2,01 & 534 \\
$100 \times$ Mo & 5055 & 2,00 & $1075 \pm 18$ \\
\hline
\end{tabular}

$* * * *$ szignifikancia szint $0,1 \%,{ }^{\text {nsz }}=$ nem szignifikáns

Table 5. The nitrate $\left(\mathrm{NO}_{3}-\mathrm{N}\right)$, nitrite $\left(\mathrm{NO}_{2}-\mathrm{N}\right)$ and ammonium nitrogen $\left(\mathrm{NH}_{4}-\mathrm{N}\right)$ concentrations ( $\mathrm{mg} \mathrm{kg}^{-1}$ ) of the roots of maize seedlings grown in nutrient solution $\varnothing$ Mo (nutrient solution without molybdenum), $1 \times$ Mo $(0.01 \mu \mathrm{M}), 10 \times$ Mo and $100 \times$ Mo treatments. (1) Mo treatments. ${ }^{* * *}=0.1 \%$ significance level, ${ }^{\mathrm{ns}}=$ not significant.

6. táblázat. Tápoldaton nevelt kukorica csíranövények variancia-analízise, függó változó a növény száraz tömege ( $\mathrm{g}$ )

\begin{tabular}{lcccrc}
\hline \multicolumn{1}{c}{\begin{tabular}{c} 
Forrás \\
\multicolumn{1}{c}{$(1)$}
\end{tabular}} & $\begin{array}{c}\text { Eltérés } \\
\text { négyzetösszeg }\end{array}$ & $\begin{array}{c}\text { Szabadság- } \\
\text { fok }\end{array}$ & $\begin{array}{c}\text { Variancia } \\
\text { (2) }\end{array}$ & $\begin{array}{c}\text { F-érték } \\
\text { (3) }\end{array}$ & $\begin{array}{c}\text { Számított } \\
\text { szignifikancia }\end{array}$ \\
\hline Regresszió (7) & $0,124(\mathrm{a})$ & 7 & 0,018 & 20,758 & 0,000 \\
Korrekciós tényezö (8) & 0,782 & 1 & 0,782 & 919,826 & 0,000 \\
Növényi rész (9) & 0,108 & 1 & 0,108 & 126,600 & 0,000 \\
Mo-kezelés (10) & 0,013 & 3 & 0,004 & 5,124 & 0,011 \\
Növényi rész * & 0,003 & 3 & 0,001 & 1,110 & 0,374 \\
Mo-kezelés (11) & 0,014 & 16 & 0,001 & & \\
Hiba (12) & 0,919 & 24 & & & \\
Összesen (13) & 0,137 & 23 & & & \\
Korrigált összesen (14) & & & & & \\
\hline
\end{tabular}

(a) R-négyzet=0,901 (Korrigált R-négyzet=0,857)

Table 6. Variance analysis of maize seedlings grown in nutrient solution. The dependent variable is the dry mass of crops (g). (1) Source, (2) Sum of squares, (3) Degree of freedom, (4) Variance, (5) F value, (6) Calculated significance, (7) Regression, (8) Correction factor, (9) Vegetation, (10) Mo treatment, (11) Vegetation * Mo treatment, (12) Error, (13) Total, (14) Corrected total. (a) R squared $=0.901($ Corrected $\mathrm{R}$ squared $=0.857)$. 


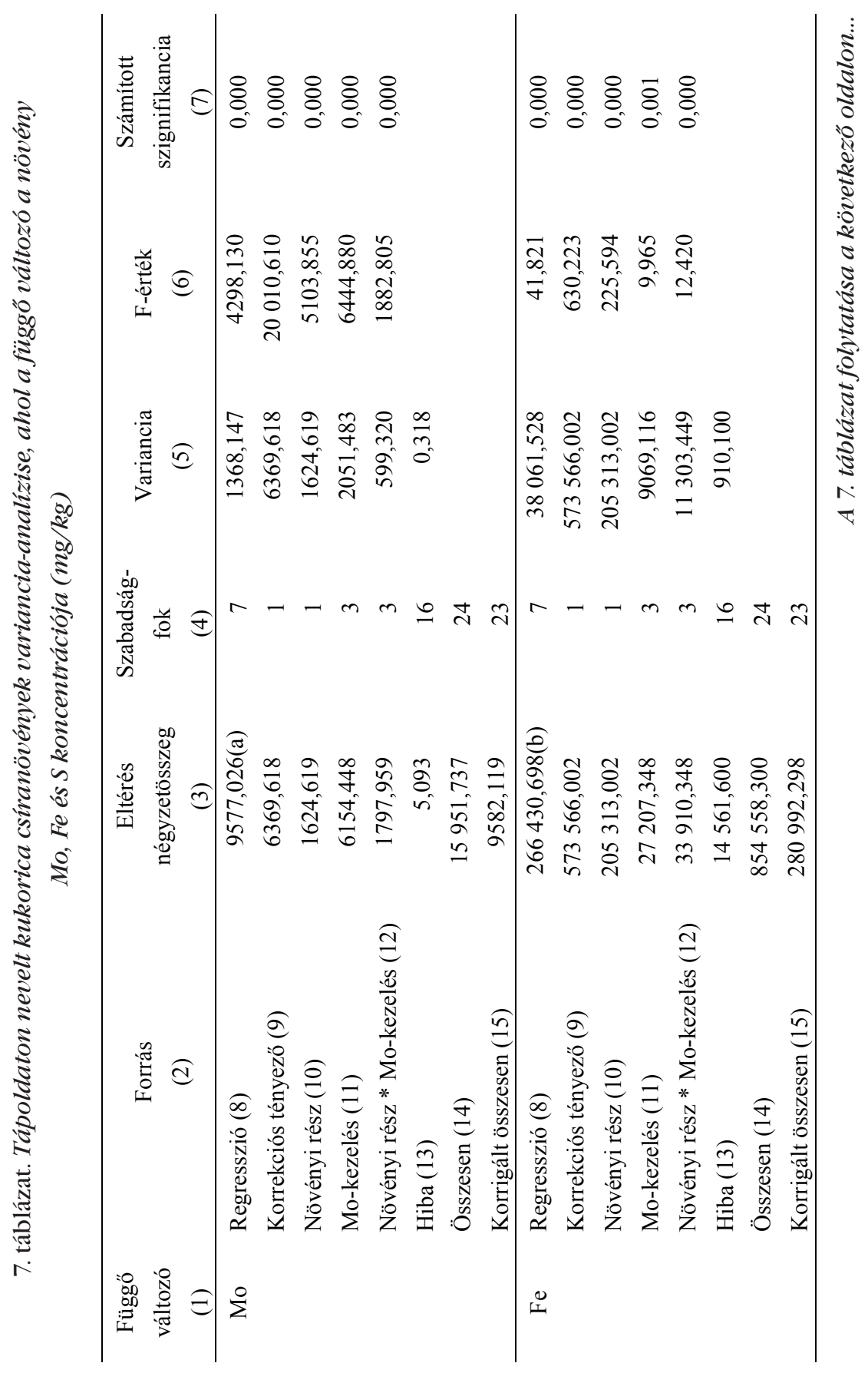




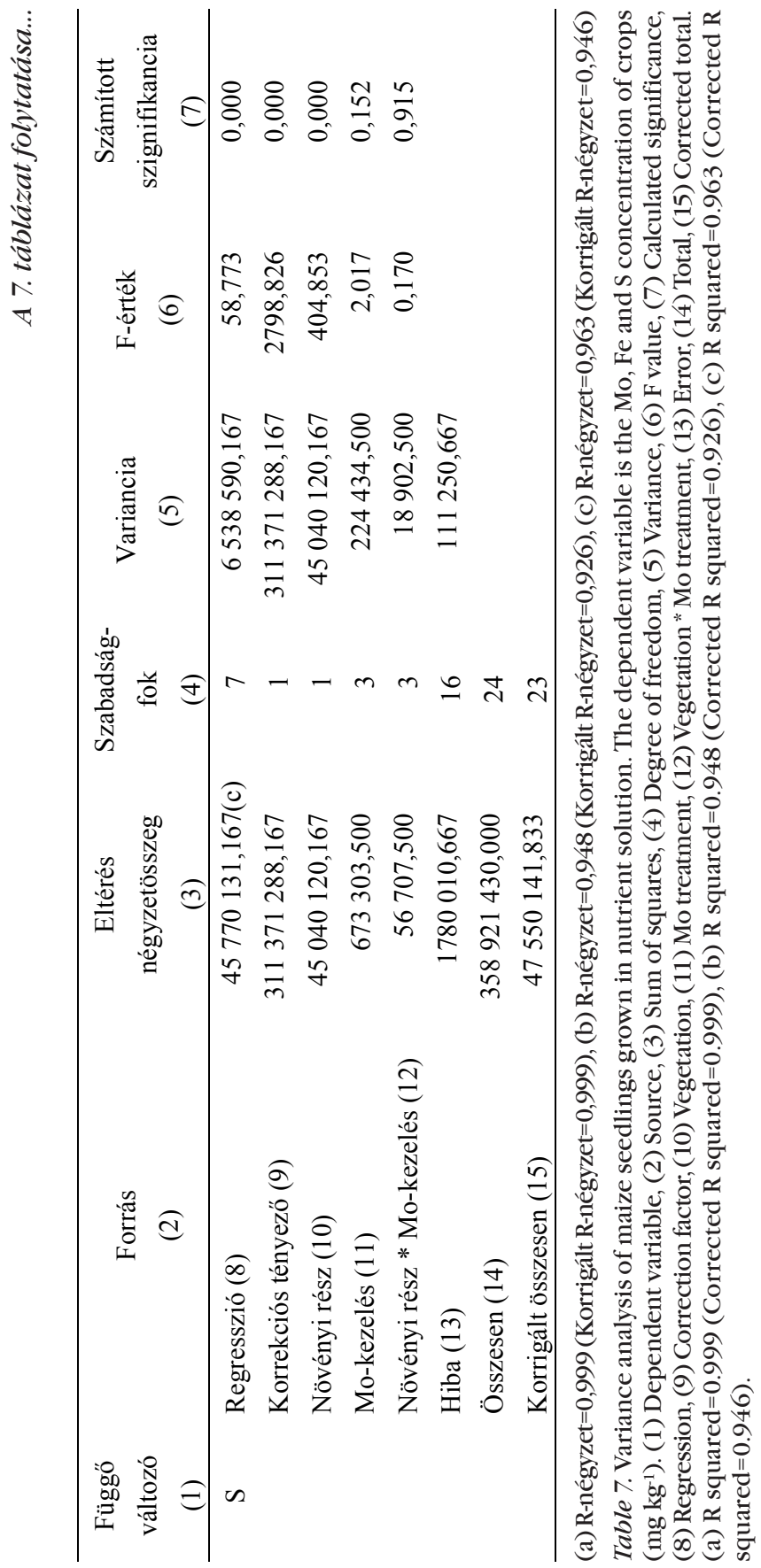




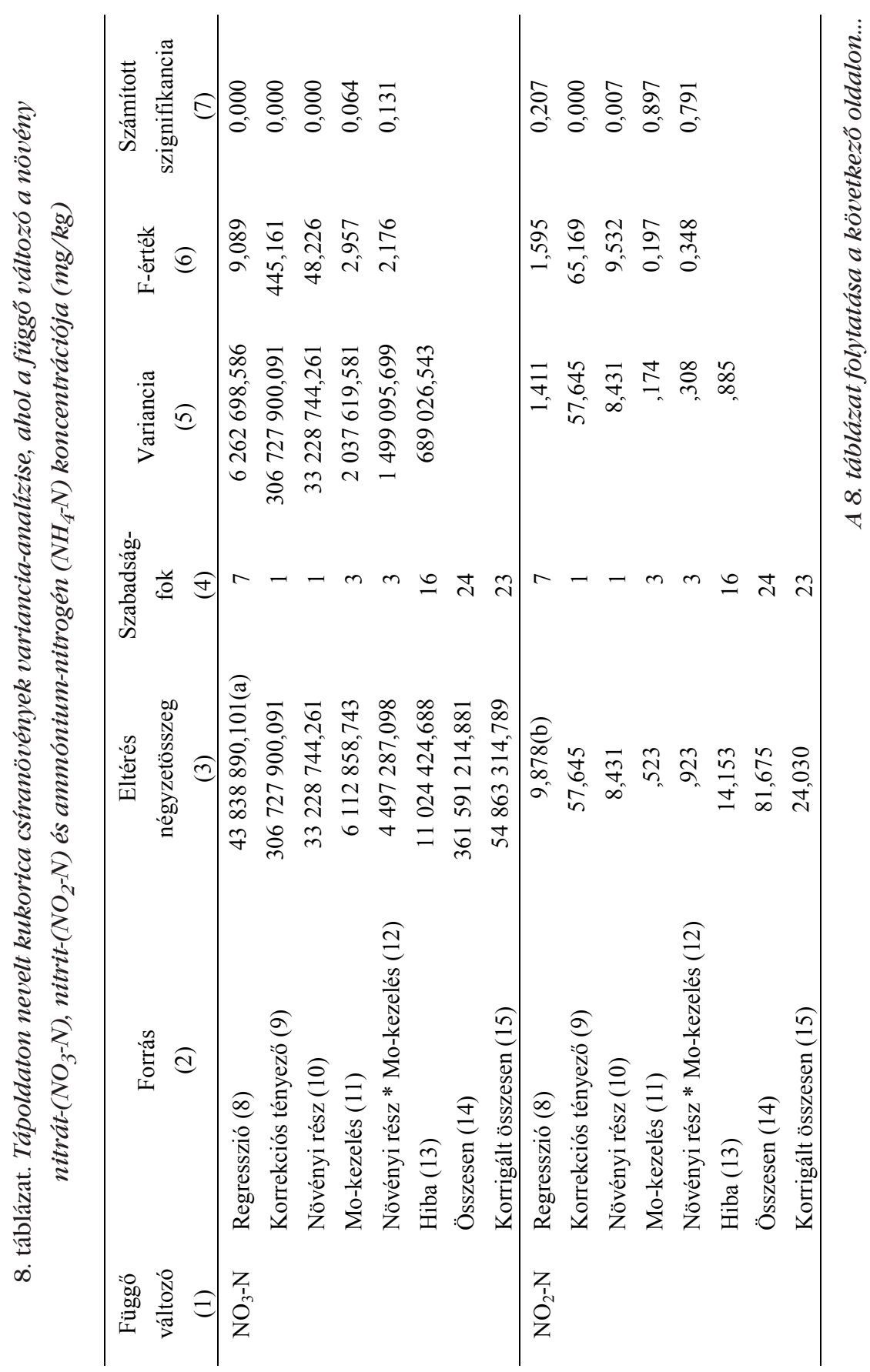




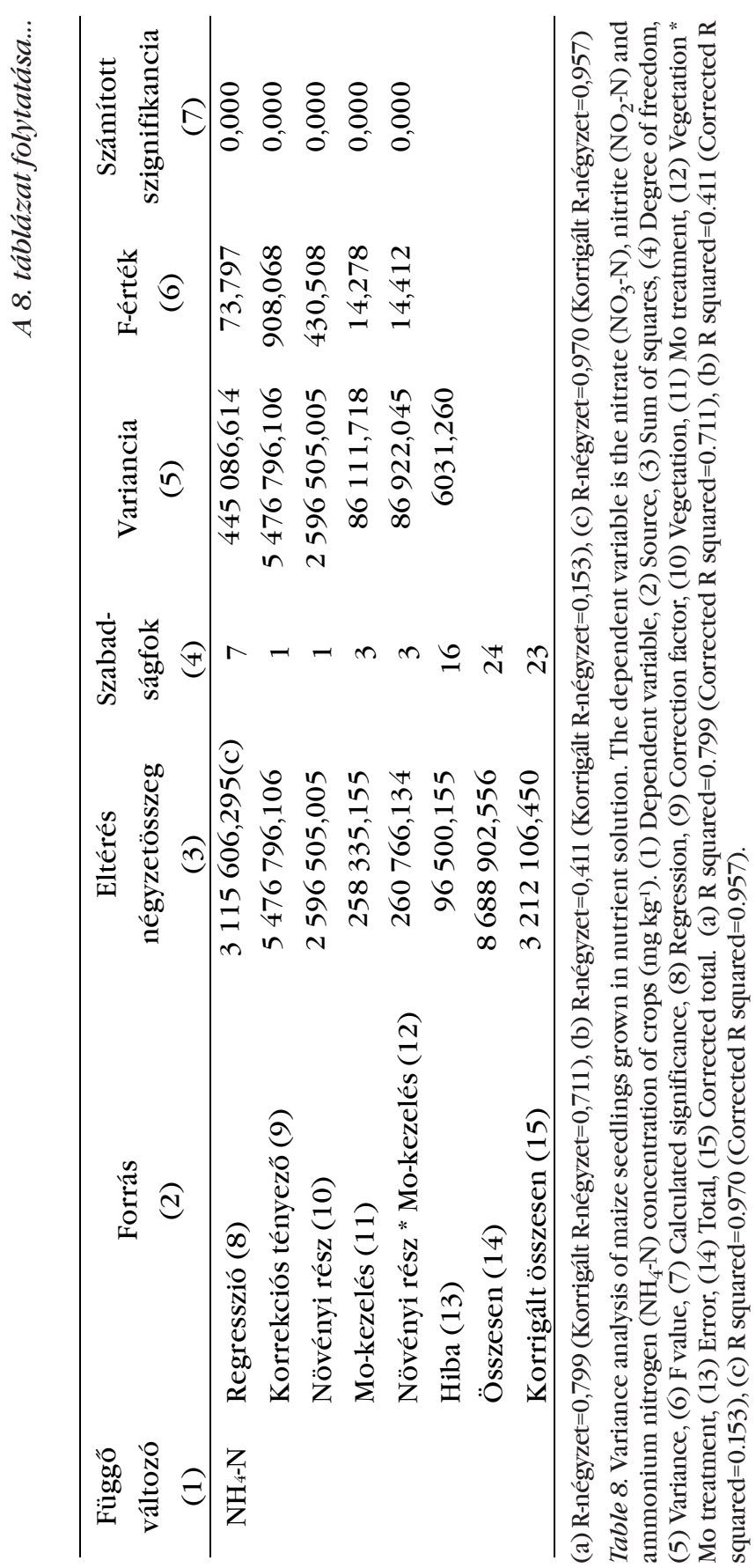


Az $\mathrm{NH}_{4}$ - $\mathrm{N}$ mennyiségét a növényi rész és a molibdénkezelés együttesen befolyásolták. Együttes hatásuk 95,7\%-ban határozta meg ennek a nitrogénformának a mennyiségét. Azonban itt is sokkal erősebb a növényi rész hatása. Meg kell jegyezni, hogy a $\mathrm{NO}_{2}-\mathrm{N}$ tartalom statisztikai vizsgálatakor a varianciaanalízis modellje nem volt szignifikáns, az $R^{2}$ értéke nagyon alacsony $(0,411)$ volt.

\section{Rizoboxban végzett kísérlet}

A növekvô koncentrációjú Mo-kezelések, kísérleti növényünk Mo-koncentrációjára kifejtett hatását az 1. ábra foglalja össze.

Az 1. ábra alapján arra a következtetésre jutottunk, hogy a kontrolltalajból a kukorica csíranövény csekély mennyiségú molibdént vett fel. A molibdén koncentrációja a hajtásban és a gyökérben is alacsony volt, majd az egyes Mokezelések hatására növekedés volt megfigyelhetô. Bár a rizoboxos kísérletünkben nem alkalmaztunk ismétléseket, a tápoldatos kísérletünkben ugyanez a tendencia volt megfigyelhető, amely megerősíti a rizoboxos kísérletünk mérési eredményeit. Hasonló eredményekre jutott Kádár (1995) Nagyhörcsökön, mészlepedékes csernozjom talajon beállított mikroelemekkel végzett terhelési kísérlete során. Az általuk beállított Mo-koncentrációk megegyeztek a kísérletünkben alkalmazottakkal és a vizsgálati növényük szintén kukorica volt. Azt tapasztalták, hogy a kukoricánál kiugróan magas Mo-akkumulációt eredményezett a terhelés, viszont a mért Mo-koncentrációknál (kivétel: a kontroll kezelés) csak kismértékú eltérések figyelhetők meg a föld feletti és a földalatti szervekben, ugyanis a gyökérben és a hajtásban mért Mo-koncentrációk hányadosa a kezeléseknél a következők voltak: 10; 1,30; 1,60; 1,26. A kísérletünkben ezek az értékek az alábbiak: 1,17; 2,98; 2,25; 2,07. Ezekből az értékekből kitûnik, hogy a kísérletünkben, a kukorica gyökerében egy intenzívebb koncentrációnövekedés következett be.

A molibdén kezelések hatottak a különböző N-formákra is. A kukorica hajtások $\mathrm{NO}_{3}$-N tartalma változó, a legalacsonyabb és a legmagasabb Mo-kezeléseknél mértük a legmagasabb értékeket (9. táblázat). 
1. ábra. Rizoboxban nevelt kukorica csíranövények hajtásainak és gyökereinek Mo-koncentrációja

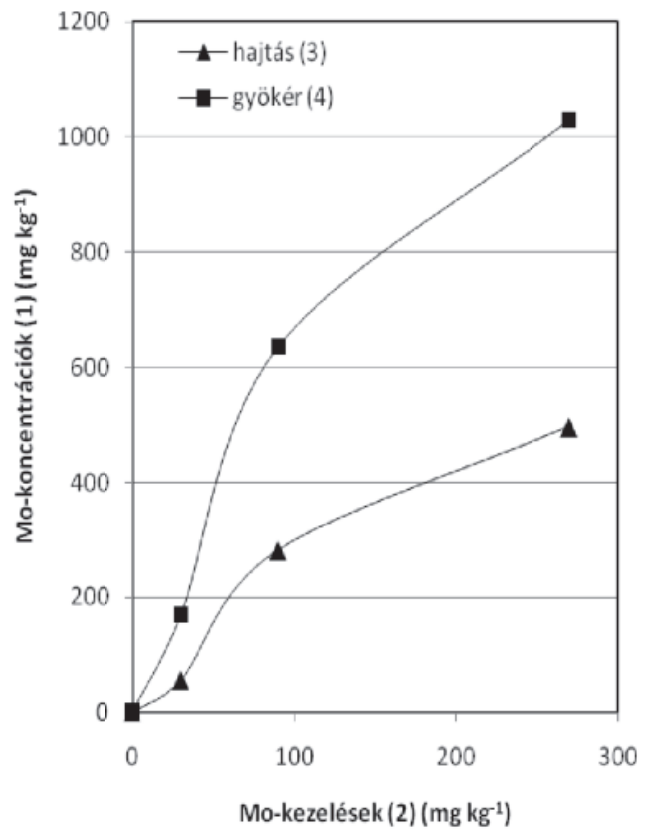

Figure 1. Mo concentration of the shoots and roots of maize seedlings grown in rhizoboxes. (1) Mo concentrations ( $\mathrm{mg} \mathrm{kg}^{-1}$ ), (2) Mo treatments ( $\mathrm{mg} \mathrm{kg}^{-1}$ ), (3) Shoot, (4) Root.

Összevetve ezeket az eredményeket Kádár et al. (2000) méréseivel, különbséget fedezhetünk fel. Kísérletükben, ammónium-paramolibdenát terhelésnél egyértelmú $\mathrm{NO}_{3}-\mathrm{N}$ koncentrációemelkedés következett be. Feltételezése szerint ennek az az oka, hogy az $\mathrm{NH}_{4}$-formában adott $\mathrm{N}$ ekkorra már nitrifikálódott, és ezt az emelkedett kínálatot tükrözhették a levelek. $\mathrm{Az} \mathrm{NH}_{4}-\mathrm{N}$ koncentrációja nőtt a hajtásokban a növekvő molibdén koncentrációknak megfelelôen, ami határozott összefüggést sejtet a Mo-kezelések és a nitrát intenzívebb redukciója között. A gyökerek esetében a Mo-kezelések csökkentették a gyökerek $\mathrm{NO}_{3}-\mathrm{N}$ tartalmát, és növelték az $\mathrm{NH}_{4}-\mathrm{N}$ koncentrációját, ami a gyökerek intenzív nitrát-reduktáz aktivitását jelenti. A felvett nitrát jelentôs része ammóniummá redukálódik, ami viszont glutaminsavhoz kapcsolódva, transzaminálási reakciókon keresztül részt vesz az aminosavak, és ezáltal a fehérjék szintézisében. 
9. táblázat. Rizoboxos kukorica csíranövények hajtásainak nitrát-( $\left.\mathrm{NO}_{3}-\mathrm{N}\right)$, nitrit-( $\left.\mathrm{NO}_{2}-\mathrm{N}\right)$ és ammónium-nitrogén $\left(\mathrm{NH}_{4}-\mathrm{N}\right)$ koncentrációja ( $m g / k g)$ különbözó molibdén-kezelések esetén ( $m g / k g)$

\begin{tabular}{cccc}
\hline $\begin{array}{c}\text { Mo-kezelések } \\
(1)\end{array}$ & $\mathrm{NO}_{3}-\mathrm{N}$ & $\mathrm{NO}_{2}-\mathrm{N}$ & $\mathrm{NH}_{4}-\mathrm{N}$ \\
\hline $\mathrm{k}$ & 41,5 & 0,424 & 237 \\
30 & 0,736 & 0,681 & 331 \\
90 & 8,44 & 0,102 & 308 \\
270 & 214 & 1,51 & 401 \\
\hline
\end{tabular}

Table 9. Nitrate $\left(\mathrm{NO}_{3}-\mathrm{N}\right)$, nitrite $\left(\mathrm{NO}_{2}-\mathrm{N}\right)$ and ammonium nitrogen $\left(\mathrm{NH}_{4}-\mathrm{N}\right)$ concentration of crops $\left(\mathrm{mg} \mathrm{kg}^{-1}\right)$ of the shoots of maize seedlings grown in rhizoboxes in the case of various molybdenum treatments $\left(\mathrm{mg} \mathrm{kg}^{-1}\right)$. (1) Mo treatments.

Az egyértelmú a kísérletek eredményeiből, hogy a Mo-szint és a $\mathrm{NO}_{3}-\mathrm{N}$ felvétele, valamint a nitrát redukciója között szoros összefüggés van, azonban az ammónium mért értékei feltehetôen alacsonyabbak, mint amire a nitrát-reduktáz aktivitásából következtetni lehetne, az említett lekötődések miatt. A rendszer finoman szabályozott, ugyanis az ammónium nem halmozódhat fel a szövetekben.

A szabad ammónium magas koncentrációja sejtméreg, ugyanis az energetizáló membránokba (elsôsorban mitokondriális) beépülve szétkapcsoló faktorként funkcionál, azaz ATP szintézise nélkül depolarizálja a membránt. Miután a növényeink nem mutattak toxikus tüneteket, feltételezzük, hogy az ammónium megkötéséhez elegendő glutaminsav állt rendelkezésre. Ebből viszont arra következtethetünk, hogy a glutaminsav szénvázat adó citromsavciklus, azaz a légzés dehidrogenáló fázisának ez a szakasza is aktív volt. Mindez intenzív anyagcserére utal, amiben a molibdén szerepe a kísérleteinkben is bizonyított. A hajtásnál tett megállapítások a kukorica gyökereire is igazak. Mindez azt jelenti, hogy a rizoboxos kísérletekben a kukorica gyökereinek és hajtásainak nitrát-reduktáz aktivitása közel azonos intenzitású (10. táblázat). 
10. táblázat. Rizoboxos kukorica csíranövények gyökereinek nitrát- $\left(\mathrm{NO}_{3}-\mathrm{N}\right)$, nitrit- $\left(\mathrm{NO}_{2}-\mathrm{N}\right)$ és ammónium-nitrogén $\left(\mathrm{NH}_{4}^{-\mathrm{N}}\right)$ koncentrációja ( $m g / k g$ ) különbözö molibdén-kezelések esetén ( $\mathrm{mg} / \mathrm{kg}$ )

\begin{tabular}{cccc}
\hline $\begin{array}{c}\text { Mo-kezelések } \\
(1)\end{array}$ & $\mathrm{NO}_{3}-\mathrm{N}$ & $\mathrm{NO}_{2}-\mathrm{N}$ & $\mathrm{NH}_{4}-\mathrm{N}$ \\
\hline $\mathrm{k}$ & 35,5 & 0,040 & 280 \\
30 & 15,8 & 0,040 & 334 \\
90 & 15,8 & 0,459 & 333 \\
270 & 134 & 2,84 & 200 \\
\hline
\end{tabular}

Table 10. Nitrate $\left(\mathrm{NO}_{3}-\mathrm{N}\right)$, nitrite $\left(\mathrm{NO}_{2}-\mathrm{N}\right)$ and ammonium nitrogen $\left(\mathrm{NH}_{4}-\mathrm{N}\right)$ concentration of crops $\left(\mathrm{mg} \mathrm{kg}^{-1}\right)$ of the roots of maize seedlings grown in rhizoboxes in the case of various molybdenum treatments $\left(\mathrm{mg} \mathrm{kg}^{-1}\right)$. (1) Mo treatments.

\section{Következtetések és javaslatok}

A tápoldatos kísérleteink során a molibdén nélküli tápoldaton mért Mo-koncentrációk megmutatták, hogy mennyi Mo volt eredetileg a csíranövényekben. Ez az érték a hajtásban alacsonyabb volt, mint a gyökérben. A kísérletnél alkalmazott Mo-kezelések megemelték a csíranövények Mo-koncentrációját, viszont eltérést figyeltünk meg a hajtás és a gyökér koncentrációi növekedésének intenzitásában. A gyökérben intenzívebb koncentrációnövekedést tapasztaltunk. Ez arra utal, hogy a gyökerekben, a vizsgált körülmények között a nitrát akkumulációja intenzívebb volt. A molibdénnel ellentétben a vas és a kén koncentrációjában a legtöbb esetben nem következett be lényeges változás, vagyis a növekvố koncentrációjú Mo-kezelésnek nem volt jelentôs befolyásoló hatása ezekre az elemekre.

Rizoboxos kísérleteinkben a Mo-felvétel hasonlóan alakult, mint a tápoldatos kísérleteinkben. A rizoboxos kísérletnél nem lehet molibdénmentes környezetet biztosítani, mivel már a kontroll talaj is tartalmaz bizonyos mennyiségú molibdént. Ennek ellenére a kontroll talajból a kukorica csíranövény viszonylag csak csekély mennyiségú molibdént vett fel.

A tápoldatos kísérlethez hasonlóan a gyökerekben mért Mo-koncentrációk magasabbak voltak a hajtásban mért értékeknél, és a kén esetében továbbra sem tapasztaltunk lényeges változást. A Mo-kezelések hatottak a különböző N-formákra is. A kísérletek eredményei alapján egyértelmú bizonyítékot találtunk 
arra vonatkozóan, hogy a molibdénellátás és a nitrát redukciója között szoros összefüggés van. Azokban az esetekben, amikor a Mo-kezelések csökkentették a gyökerek $\mathrm{NO}_{3}-\mathrm{N}$ tartalmát és növelték az $\mathrm{NH}_{4}-\mathrm{N}$ koncentrációját, egy intenzívebb nitrát-reduktáz aktivitást feltételezünk.

Egyes esetekben a várásunknak megfelelően a fiziológiai Mo-igényt kielégítve $(1 \times \mathrm{Mo}=0,01 \mu \mathrm{M})$ csökkent $\mathrm{NO}_{3}-\mathrm{N}$ koncentrációt és a molibdénmentes tápoldatban mértnél jóval nagyobb $\mathrm{NH}_{4}-\mathrm{N}$ tartalmat kaptunk. Ez arra utal, hogy a nitrát redukciója sokkal intenzívebb kiegyenlített Mo-ellátás esetén. Kísérleteink során arra is találtunk példát, hogy az $\mathrm{NH}_{4}-\mathrm{N}$ koncentrációja csak a tízszeres Mo-kezelésig nőtt, majd százszoros Mo-kezelésnél jelentősen visszaesett. Ebben az esetben az alkalmazott Mo-koncentráció már gátolta a nitrátreduktáz aktivitását.

Kísérletünk során arra a következtetésre jutottunk, hogy szoros összefüggés van a növények molibdénellátása és nitrátredukciója között, mivel a nitrátredukció intenzitását alapvetôen meghatározza a nitrát-reduktázban jelenlévő molibdén mennyisége. Molibdén hiányában e folyamat lelassul és ez a nitrát felhalmozódását eredményezi, viszont megfelelő molibdénellátással biztosítani tudjuk a levél- és gyökérzöldségek, de általában a friss, zöld fogyasztású termékek csökkentett nitrát tartalmát. Viszont itt fontosnak tartjuk megemlíteni, hogy a talaj Mo-koncentrációja mellett a friss zöldségek $\mathrm{NO}_{3}-\mathrm{N}$ tartalmát jelentősen befolyásolják a fényviszonyok, valamint a nappalok hossza is, így az üvegházi körülmények között nagyságrenddel nagyobb lehet a $\mathrm{NO}_{3}-\mathrm{N}$ koncentráció a növényben.

A talaj Mo-ellátásánál fontos figyelembe vennünk azt a tényt, hogy bár jelenléte elengedhetetlen a nitrát-reduktáz enzim múködéséhez, túl magas koncentrációja viszont komoly veszélyt jelent. Bár a növényeknél általában még nagyfokú Mo-akkumuláció esetén sem lép fel anyagcserezavar, nem jelentkezik fitotoxikus hatás, az állatoknál ez a koncentráció már molibdéntoxikózist okozhat. A betegség kialakulásának kockázata már $5 \mathrm{mg} / \mathrm{kg}$ Mo-tartalom felett jelentős, amirôl nem feledkezhetünk meg az állatok takarmányozásakor.

\section{Köszönetnyilvánítás}

A szerzôk köszönik a Bolyai János Kutatási Ösztöndíj támogatását. 


\section{IRODALOM}

Aubert, H.-Pinta, M.: 1977. Trace elements in soils. Elsevier Scientific Publishing Company. 55-61.

Berger, K. C.-Pratt, P. F.: 1965. Advances in secondary and micronutrient fertilization. [In: McVicka, M. M.-Bridger, G. L.-Nelson, L. B. (eds.) Fertilizer technology and usage.] Soil Science Society of America. Madison. Wisconsin. USA. 287-340.

Berks, B. C.-Ferguson, S. J.-Moir, J. W. B.-Richardson, D. J.: 1995. Biochim. Biophys. Acta-Bioenergetics. 1232: 97.

Cakmak, I.-Marschner, H.: 1990. Decrease in nitrate uptake and increase in proton release in zinc deficient cotton, sunflower and buckwheat plants. Plant and Soil. 129: 261-268.

Duval, L.-More, E.-Sicot, A.: 1991. Observations on molybdenum deficiency in cauliflower in Brittany. Comtes Rendus de I Academic d Agriculture de France. 78: 27-34.

Füleky Gy.: 1999. Tápanyag-gazdálkodás. Mezőgazda Kiadó. Budapest.

Gupta, U. C.-Lipsett, J.: 1981. Molybdenum in soils, plants and animals. Adv. Agron. 34: 73-115.

Kádár I.-KonczJ.-Gulyás F.: 2000. Mikroelem-terhelés hatása a kukorica összetételére és a talaj könnyen oldható elemtartalmára karbonátos csernozjomon. Agrokémia és Talajtan. 49: 205-220.

Kádár I.: 1995. A talaj-növény-állat-ember tápláléklánc szennyeződése kémiai elemekkel Magyarországon. KTM - MTA TAKI. Budapest. 388.

Kalocsai R.-Pogány É.: 2007. A molibdén jelentősége, előfordulása a talajban, felvétele. MezôHír. 11: 62.

Katyal, J. C.-Randhawa, N. S.: 1983. Micronutrients (molybdenum). FAO Fert. Plant Nutr. Bull. 7: 69-76.

Knowles, R. G.-Palacios, M.-Palmer, R.J. M.-Moncada, S.: 1989. Formation of nitric oxide from L-arginine in the central nervous system: a transduction mechanism for stimulation of the soluble guanylate cyclase. Proc. Natl. Acad. Sci. 86: 5159-5162.

Kovács, B.-Gyóri, Z.-Prokisch, J.-Loch, J.-Dániel, P.: 1996. A study of plant sample preparation and inductively coupled plasma emission spectometry parameters. Commun. in Soil Science and Plant Analysis. 27. 5-8: 1177-1198.

Loch J.-Nosticzius Á.: 1992. Agrokémia és növényvédelmi kémia. Mezôgazda Kiadó. Budapest.

Nagy K.-Lévai L.-Kovács B.: 2010. A szelénellátás hatása a kukorica és napraforgó növényekre. Növénytermelés. 59. 1: 61-84.

Puskás-Preszner A.-Kovács B.: 2009. Molibdénkezelés hatása szabadföldi kísérletben a növényi felvételre és a talaj molibdén frakcióira. Agrártudományi Közlemények. Debrecen. 36: 117-122.

Reilly, C.: 1991. Metal contamination of food. Elsevier Science Publisher Ltd. 225-229. 
Schulte, E. E.: 2004. Soil and Applied Molybdenum. Understanding Plant Nutritients. Produced by Cooperative Extension Publications. University of Wisconsin. Extension.

Simon L.: 1999. Talajszennyeződés, talajtisztítás. Környezetügyi Múszaki Gazdasági Tájékoztató - 5. kötet Környezetgazdálkodási Intézet. Budapest.

Szabó S. A.-Regiusné Mốcsényi A.-Györi D.-Szentmihályi S.: 1987. Mikroelemek a mezőgazdaságban I. (Esszenciális mikroelemek). Mezőgazdasági Kiadó. Budapest.

Szalai I.: 2006. A növények élete. Ahogyan ma látjuk I. Nemzeti Tankönyvkiadó Zrt. Budapest.

A szerzók levelezési címe - Address of the authors:

Bódi Éva-Dr. Lévai László-Dr. Huzsvai László-Dr. Kovács Béla

Debreceni Egyetem Agrár- és Gazdálkodástudományok Centruma

Debrecen

Böszörményi út 138.

H-4032 